\title{
Studies on the origin of faecal amino acids in cystic fibrosis ${ }^{1}$
}

J. W. T. SEAKINS, R. S. ERSSER, AND I. S. E. GIBBONS ${ }^{2}$

From the Department of Chemical Pathology, Hospital for Sick Children and the Institute of Child Health, London

SUMMARY Evidence is presented which demonstrates that excess faecal amino acids in cystic fibrosis are derived from unabsorbed dietary protein. Changes in the absorption of fat and nitrogen have little effect on the amino-acid patterns.

In an earlier paper (Gibbons, Seakins, and Ersser, 1967) it was shown that the faecal aminoacid patterns of children with cystic fibrosis were heavier than those of normal children and adults. Most of the amino acids found in proteins were involved, together with some of their decarboxylation products, amines 'and 'non-alpha amino acids. These findings were in contrast to normal faecal patterns found in an infant with Hartnup disease (Seakins and Ersser, 1967) and three children with cystinuria (unpublished observations).

Previously protein absorption in patients with cystic fibrosis and the effect of pancreatin have been studied by the balance technique (Harris, Norman, and Payne, 1955) or by the change in blood amino acids following loading tests (West, Wilson, and Eyles, 1946; Anfanger and Heavenrich, 1949). There is, however, little information on the composition of faeces and none on the possible interaction between unabsorbed constituents. In this paper, the composition of individual stools from different patients with cystic fibrosis are compared with those from normal children and adults. Further information was sought on the sources of faecal amino acids by varying the dietary protein and fat and by partial sterilization of the gut.

${ }^{1} \mathrm{~A}$ preliminary account of this work was presented at the 5th International Cystic Fibrosis Conference, Cambridge in September 1969. Please address reprint requests to J. W. T. Seakins, Institute of Child Health, 30 Guilford Street, London WCIW 1EH. 'Present address: The Hahnemann Medical College, Philadelphia, USA.

Received for publication 5 December 1969.

\section{Methods}

COLLECTION OF FAECES

Specimens were collected into containers, the time and presence or absence of marker noted. The specimens were either stored on solid carbon dioxide or at $-20^{\circ} \mathrm{C}$, which prevented further bacterial transformations, before analysis. Carmine or Edicol supra blue EG (ICI Ltd) were used as markers and were given with the first meal of the day.

\section{PREPARATION OF SAMPLES}

Preliminary investigations had shown that some faecal specimens possessed considerable proteolytic activity which resulted in a significant increase in the amino-acid pattern during the preparation of the sample for analysis. This was prevented by using dilute hydrochloric acid $(3 \%)$ to make an accurate dilution $(3: 1 \mathrm{w} / \mathrm{w})$ of the individual weighed faecal specimen in a Silverson homogenizer. The final $p \mathrm{H}$ was about 2 , and the presence of the mineral acid did not interfere with the subsequent analyses.

\section{CHROMATOGRAPHY OF AMINO ACIDS AND AMINES}

A sample of the faecal homogenate $(30 \mathrm{~g})$ was diluted to $60 \mathrm{ml}$ with acetone, shaken thoroughly, centrifuged, and the supernatant either stored at $-20^{\circ} \mathrm{C}$ or processed immediately in the following way. 
A volume of the supernatant equivalent to $3 \mathrm{~g}$ faeces was diluted with an equal volume of aqueous acetone $(1: 1)$, filtered if necessary, and passed down a column of Zeo-Karb 225 (SRC $10 \mathrm{H}^{+}, 1 \times 10 \mathrm{~cm}$ ) washed successively with water, ethanol, and water to remove absorbed pigments, etc, and the amino acids and amines displaced with $5 \mathrm{~N}$-ammonia $(25 \mathrm{ml})$. The ammoniacal effluent was taken to dryness in a rotary evaporator (a few millilitres of butanol were added to stop frothing) and the residue taken up in $10 \%$ isopropanol-water $(0.3 \mathrm{ml})$.

All specimens were examined by one-way descending chromatography for 16 hours, and a length of run of $45 \mathrm{~cm}$, on Whatman no. 3 paper with $\mathrm{nBuOH}-\mathrm{AcOH}-\mathrm{H}_{2} \mathrm{O}(120: 30: 50)$ and by two-way electrochromatography in $25.5 \mathrm{~cm}$ square sheets of Whatman no. 3 paper, $p \mathrm{H} \mathrm{2,}$ followed by ascending chromatography in the above solvent system using an amount equivalent to $100 \mathrm{mg}$ wet weight faeces (Seakins and Ersser, 1967). Amino acids and amines were visualized by ninhydrin/pyridine. The identity of the amino acids and amines was confirmed by their electrophoretic and chromatographic behaviour using authentic specimens, by their characteristic colours with the ninhydrin/pyridine and $\beta$ naphthaquinone-4-sulphonate (Folin's) reagents, and by specific location reagents (Table I); in addition diazotized sulphanilic acid (Pauly's reagent) was used to confirm the identity of tyrosine, tyramine, histidine, and histamine. Further confirmation where necessary was obtained by fractionation of the ammoniacal effluent on successive ion-exchange resins: (a) Zeo-Karb 226 (SRC 43, $p \mathrm{H} 7 \cdot 0$ pyridine acetate) which retained amines, basic amino acids, and basic peptides (Blau, 1961) which were eluted with acetic acid; (b) Zeo-Karb 225 (pyridine form) which retained the aromatic and non- $\alpha$ -

\begin{tabular}{|c|c|c|}
\hline Amino Compound & Separation & Location Reagent \\
\hline Glu, Asp & $\begin{array}{l}\text { Electrophoresis, } p \mathrm{H} 4 \cdot 4 \\
\text { pyridine acetate }\end{array}$ & $\begin{array}{l}0.2 \% \text { ninhydrin and } 5 \% \text { pyridine }^{\text {in acetone }} \text { ( }^{1}\end{array}$ \\
\hline Tyr, Phe & $\begin{array}{l}\text { Electrochromatography } \\
\text { (see text) }\end{array}$ & $\begin{array}{l}0.2 \% \text { ninhydrin and } 5 \% \text { pyridine } \\
\text { in acetone }\end{array}$ \\
\hline $\begin{array}{l}\text { Leu, Ileu, Val, } \\
\text { Tyr } \mathrm{NH}_{2}, \text { (Met) }\end{array}$ & $\begin{array}{l}\text { Test-pentanol-methyl ethyl } \\
\text { ketone-water }(60: 20: 20) \text { in } \\
\text { atmosphere of diethylamine }\end{array}$ & $\begin{array}{l}0.2 \% \text { ninhydrin and } 5 \% \text { pyridine } \\
\text { in acetone }\end{array}$ \\
\hline Ala & $\begin{array}{l}\text { n-butanol-acetic acid-water } \\
(120: 30: 50)^{1}\end{array}$ & $\begin{array}{l}0.2 \% \text { ninhydrin and } 5 \% \text { pyridine } \\
\text { in acetone }{ }^{1}\end{array}$ \\
\hline Pro, Hypro & $\begin{array}{l}\text { n-butanol-acetic acid-water } \\
(120: 30: 50)^{1}\end{array}$ & Isatin ${ }^{1}$ \\
\hline Met, $\left(\mathrm{CyS}_{\mathbf{2}}\right)$ & $\begin{array}{l}\text { n-butanol-acetic acid-water } \\
(120: 30: 50)^{1}\end{array}$ & Iodoplatinate ${ }^{\mathbf{1}}$ \\
\hline Try, Try- $\mathrm{NH}_{2}$ & $\begin{array}{l}\text { n-butanol-acetic acid-water } \\
(120: 30: 50)\end{array}$ & Ehrlich's reagent $^{1}$ \\
\hline His, Gly & $\begin{array}{l}\text { n-butanol-acetic acid-water } \\
(120: 30: 50)\end{array}$ & o-Phthalaldehyde \\
\hline
\end{tabular}

Tabie I Separation methods for the semi-quantitation of faecal amino acids and amines

'Smith (1969)

${ }^{2}$ Munier and Sarrazin (1964)

$30.5 \%$ solution in acetone, $10 \mathrm{~min}$ at $40^{\circ} \mathrm{C}$. amino acids (Kakimoto and Armstrong, 1961); (c) De-Acidite FF (SRA 62, acetate) which retained aspartic and glutamic acids (Kakimoto and Armstrong, 1961).

Amino acids were quantitated by visual comparison with standards of $2,5,10$, and $20 \mu \mathrm{g}$, and where appropriate the samples were diluted so that the concentration fell within the lower part of this range. Table I summarizes the procedures employed. Satisfactory methods could not be found for lysine, threonine, serine, and arginine, though the last three were rarely noted. Recovery experiments on authentic amino acids and a casein hydrolysate indicated an overall accuracy of between 5 and $10 \%$.

\section{AMINO NITROGEN}

The sample was prepared as described above for chromatography of amino acids and the dried ammoniacal effluent stored overnight over concentrated sulphuric acid in a vacuum dessicator to remove residual ammonia. The residue was dissolved in a suitable volume of $0 \cdot 1 \mathrm{M}$ potassium

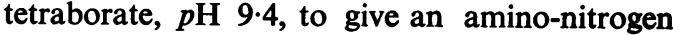
concentration between 0.02 and $0.15 \mathrm{mM}$, using the chromatogram as a guide. The amino nitrogen was determined by a trinitrobenzene sulphonic acid method (Mokrasch, 1967) as modified by Prenton and London (1967) for use on the Technicon AutoAnalyzer, but omitting the dialyzer unit. Glycine $(0 \cdot 02-0 \cdot 15 \mathrm{mM})$ was used as a standard.

Total nitrogen was determined by Kjeldahl's method using selenium dioxide as catalyst, after 'black ashing' faecal homogenates with concentrated sulphuric acid. The method of Fowweather and Anderson (1946) to evaluate faecal fat was slightly modified. Equal weights $(10 \mathrm{~g})$ of the acid faecal homogenate and plaster of paris were mixed, dried, and pulverized before extraction with petroleum spirit (boiling point, $60-80^{\circ} \mathrm{C}$ ) in a Soxhlet apparatus. A sample of this acid homogenate $(1 \mathrm{~g})$ was dried at $105^{\circ} \mathrm{C}$ for $24 \mathrm{hr}$ and reweighed to measure water content. Urinary phenolic acids were isolated and chromatographed according to the methods described by Smith, Seakins, and Dayman (1969).

\section{Clinical Material}

\section{NORMAL SUBJECTS}

The three normal adults are the authors of this paper. A total of 48 children (6 months-15 years) who were inpatients at the Hospital for Sick Children served as normal controls. They were either awaiting or recovering from minor surgical operations or were mentally retarded children admitted for assessment. All were receiving normal ward diets, had normal bowel motions at the time of collection, had no history of 
malabsorption or metabolic disease, and were not receiving antibiotics. The son of one of the authors (J.S.) acted as a further control, and specimens were collected at home.

\section{PATIENTS}

A total of 55 patients ( 3 months- 15 years) with a proven diagnosis of cystic fibrosis of the pancreas were studied. Of these, eight patients (3 months-2 years) were newly diagnosed and had not received any therapy. Where possible at

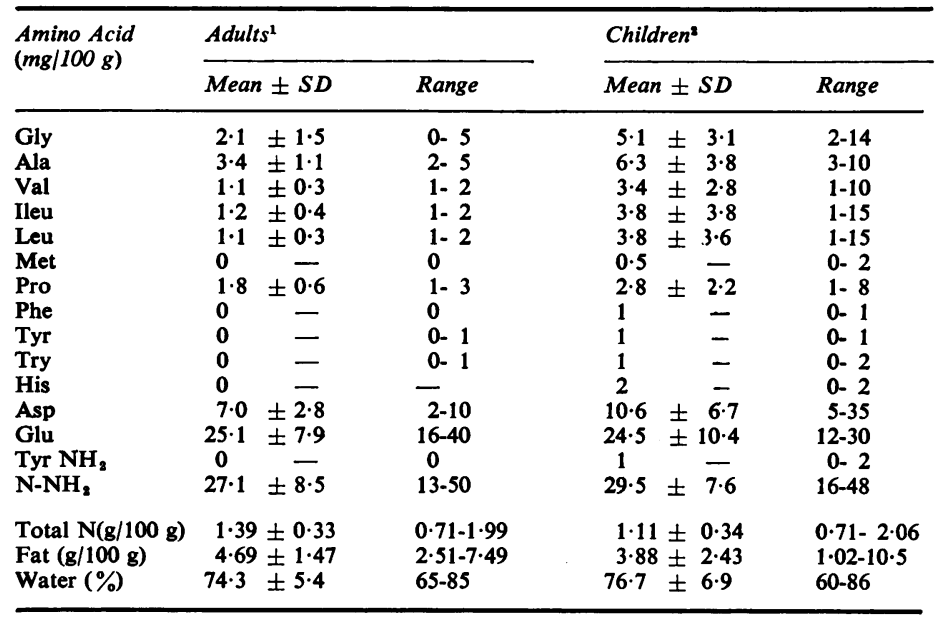

Table II Faecal amino acids in normal subjects ${ }^{1}$ Three adults, 16 specimens. 'Fifteen children, 21 specimens.

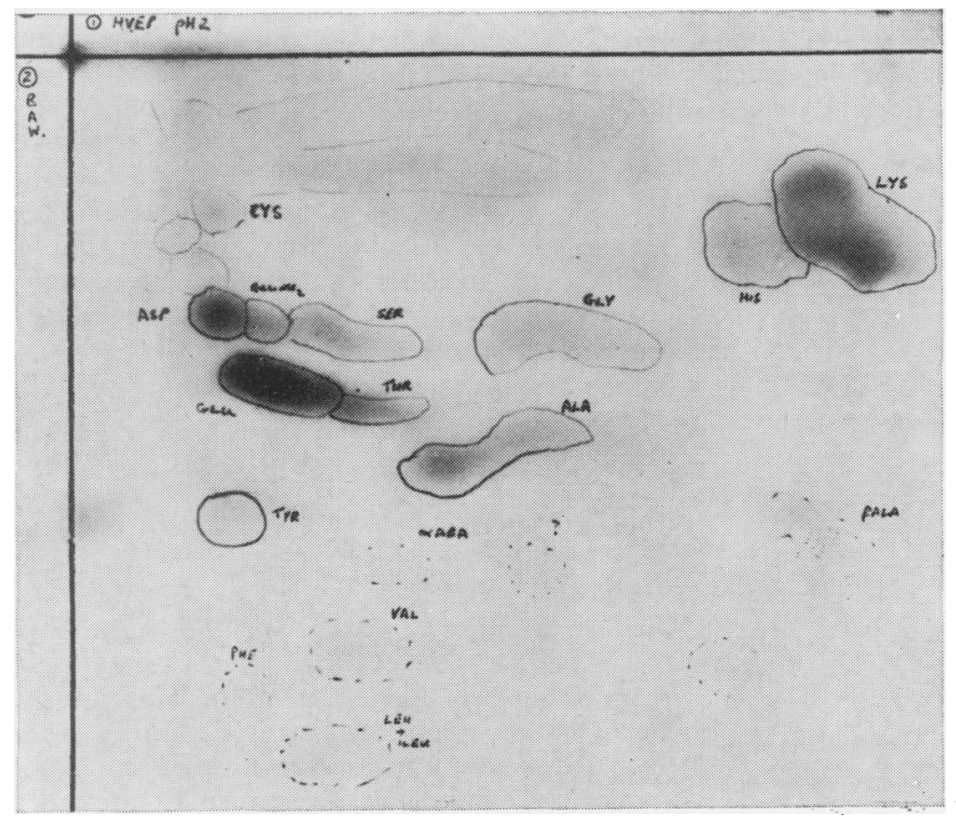

Fig. 1 Two-way electrochromatogram from a normal subject. least three separate specimens were examined. Pancreatin supplements were given as either Pancrex V powder or capsules, 0.5-2 $\mathrm{g}$ four times daily with meals, or as an enteric-coated preparation, Pancrex V Forte tablets, 2-6 tablets four $\Rightarrow$ times daily before meals (Paines and Byrne Ltd, Greenford).

\section{Results}

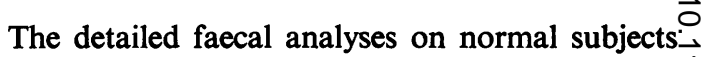
are presented in Table II. Figure 1 is a typical $\vec{\omega}$ two-way electrochromatogram. A further $51 \frac{\Omega}{6}$ specimens from 34 children were examined by one-way chromatography and by two-way electro- chromatography only. Qualitatively, all patterns $-V$ were similar. Lysine was present in most speci- 8 mens, but was not quantitated. No change in the pattern of amino acids was observed whens two adults took methyl cellulose $\left(10 \mathrm{~g} /\right.$ day for ${ }_{c}^{-}$ four days) to increase faecal bulk, nor when a normal boy was given pancreatin.

Figure 2 is a typical two-way electrochromato- $-\overrightarrow{0}$ gram from a patient with cystic fibrosis. The. detailed analyses on the 15 patients with cystic fibrosis are summarized in Table III and in Figures 3 and 4 . The variations in isoleucine and valine content approximately paralleled that of leucine; aspartic acid was always within the $\stackrel{\mathbb{Q}}{\mathbb{Q}}$ normal range, in contrast to glutamic acid; $\overrightarrow{\overrightarrow{0}}$ tryptophan, proline, and methionine were ele- 3 vated in about one third of the patients; excess lysine was present in most patients. Additionally? variable amounts of $\delta$-aminovaleric, $\alpha$ - and $\gamma=0$ amino-n-butyric acids, $\beta$-alanine, ethanolamine, cadaverine, and less frequently histamine and 3 putrescine were observed. One-way chromatograms and two-way electrochromatograms from the remaining $\mathbf{4 0}$ children with cystic fibrosis gave a similar range in faecal amino-acid patterns.

The water content of faeces from the 15 patients $\frac{7}{0}$ with cystic fibrosis was in the normal range (overall mean $75 \cdot 1 \pm 3.7 \%$; Fig. 5) with the exception of three specimens from three patients $\mathrm{N}$ which had a very high fat content $(25-30 \%)$ and aN low water content (approximately 50\%). These ${ }_{\sigma}^{\omega}$ specimens were not included in the above mean value. For a given patient, it was noted that a? higher fat content was associated with a lower@ water content (see also Table IV).

The faecal nitrogen $(1.28 \pm 0.33 \mathrm{~g} / 100 \mathrm{~g})$ was not significantly different from normal subjects, although the actual daily loss of nitrogen was $\widetilde{\mathbb{D}}^{2}$

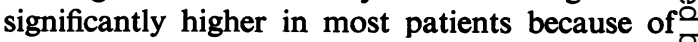
the increased faecal bulk. The fat content varied considerably (Fig. 5) and no relationship between 8 faecal amino nitrogen, total nitrogen, fat, and? bulk eould be discerned. This is exemplified byô comparing the detailed figures in two patients. $?$ In the first patient (no. 6) faecal fat $(3.4 \pm 0.8$ $\mathrm{g} / 100 \mathrm{~g})$ and nitrogen $(0.82 \pm 0.08 \mathrm{~g} / 100 \mathrm{~g})$ were 
OH.PEF. PHZ

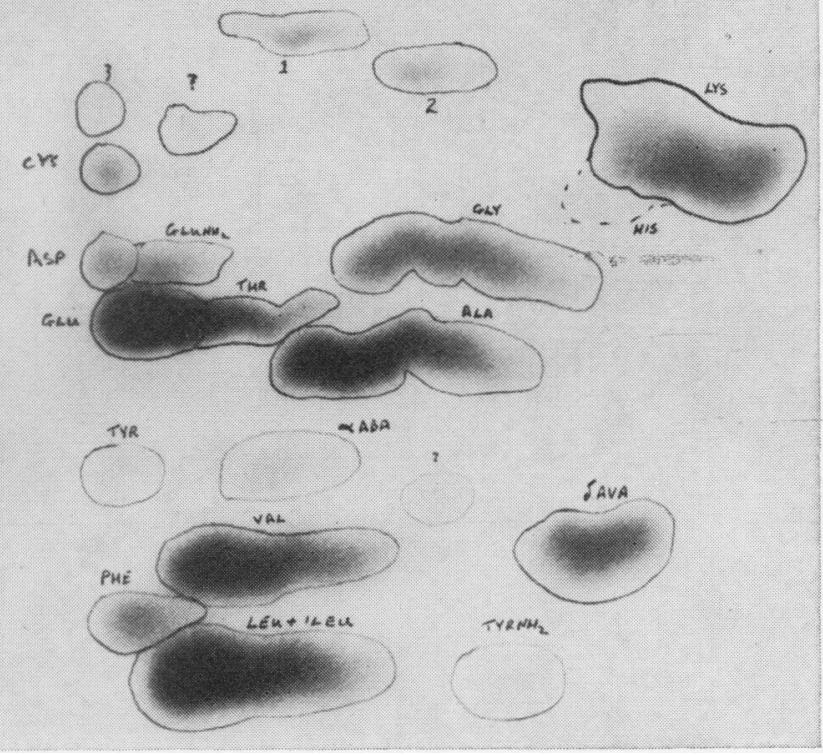

Fig. 2 Two-way electrochromatogram from a patient with cystic fibrosis. normal as were the corresponding daily faecal outputs, $4.9 \mathrm{~g}$ fat and $1.11 \mathrm{~g}$ nitrogen, but there was a heavy amino-acid pattern in all specimens. In the second patient (no. 15), the faecal nitrogen was normal $(1.67 \pm 0.10 \mathrm{~g} / 100 \mathrm{~g})$, the faecal fat was elevated $(15.4 \pm 7.7 \mathrm{~g} / 100 \mathrm{~g})$, and the corresponding daily outputs were grossly increased, being respectively $4.8 \mathrm{~g}$ and $47.7 \mathrm{~g}$, but the amino nitrogen was just outside the normal range.

Over two-thirds of the patients studied gave an elevated urinary excretion of p-hydroxyphenylacetic acid, but there was no clear correlation between faecal tyramine and the excretion of its urinary metabolite.

\section{CHANGE IN NATURE AND QUANTITY OF DIETARY FAT}

Four variations in diet were investigated in patient no. 5 (Table III). As far as possible diets were isonitrogenous and isocaloric. Faecal analyses were performed for each period on six consecutive specimens collected at least one week after the change in diet. Table IV summarizes the effects of these changes.

The transit time remained unchanged throughout at approximately 24 hours, although the

\begin{tabular}{|c|c|c|c|c|c|c|c|c|c|c|c|c|c|c|c|}
\hline & \multicolumn{15}{|c|}{ Case No. } \\
\hline & 1 & 2 & 3 & 4 & 5 & 6 & 7 & 8 & 9 & 10 & 11 & 12 & 13 & 14 & 15 \\
\hline Age (yr) & 0.3 & $1 \cdot 5$ & 3 & 3 & $3 \cdot 8$ & 4 & 4 & 8 & 9 & 10 & 11 & 11 & 12 & 12 & 16 \\
\hline Sex & $\mathbf{M}$ & $\mathbf{F}$ & $\mathbf{M}$ & $\mathbf{F}$ & $\mathbf{F}$ & $\mathbf{M}$ & $\mathbf{M}$ & $\mathbf{F}$ & $\mathbf{M}$ & $\mathbf{F}$ & $\mathbf{F}$ & $\mathbf{M}$ & $\mathbf{M}$ & $\mathbf{M}$ & $\mathbf{M}$ \\
\hline Mean nitrogen $(\mathrm{g} / 100 \mathrm{~g})$ & 0.96 & - & 1.86 & 1.52 & $2 \cdot 07$ & 0.82 & $1 \cdot 19$ & $1 \cdot 16$ & $1 \cdot 04$ & $1 \cdot 45$ & - & $1 \cdot 32$ & $1 \cdot 54$ & $1 \cdot 41$ & $1 \cdot 67$ \\
\hline Pancreatin 1 & $\mathbf{P}$ & $\mathbf{0}$ & $\mathbf{0}$ & $\mathbf{P}$ & $\mathbf{0}$ & $\mathbf{P}$ & $\mathbf{P}$ & $\mathbf{P}$ & $\mathbf{P}$ & $\mathbf{P}$ & $\mathbf{O}$ & $\mathbf{P}$ & & $\mathbf{P}$ & $\mathbf{P}$ \\
\hline Transit time (hr) & $\begin{array}{l}22 \\
26\end{array}$ & - & - & $\begin{array}{l}25 \\
32\end{array}$ & 24 & $\begin{array}{l}23 \\
25\end{array}$ & $\begin{array}{l}25 \\
29\end{array}$ & $\begin{array}{r}6 \\
26\end{array}$ & - & 96 & 35 & - & 22 & - & $\begin{array}{l}14 \\
45\end{array}$ \\
\hline No. of specimens & 3 & 2 & 2 & 6 & 6 & 5 & 4 & 9 & 3 & 6 & 3 & 3 & 3 & 5 & 4 \\
\hline
\end{tabular}

Table III Data on children with cystic fibrosis

${ }^{1} P$, receiving pancreatin; $O$, off pancreatin.

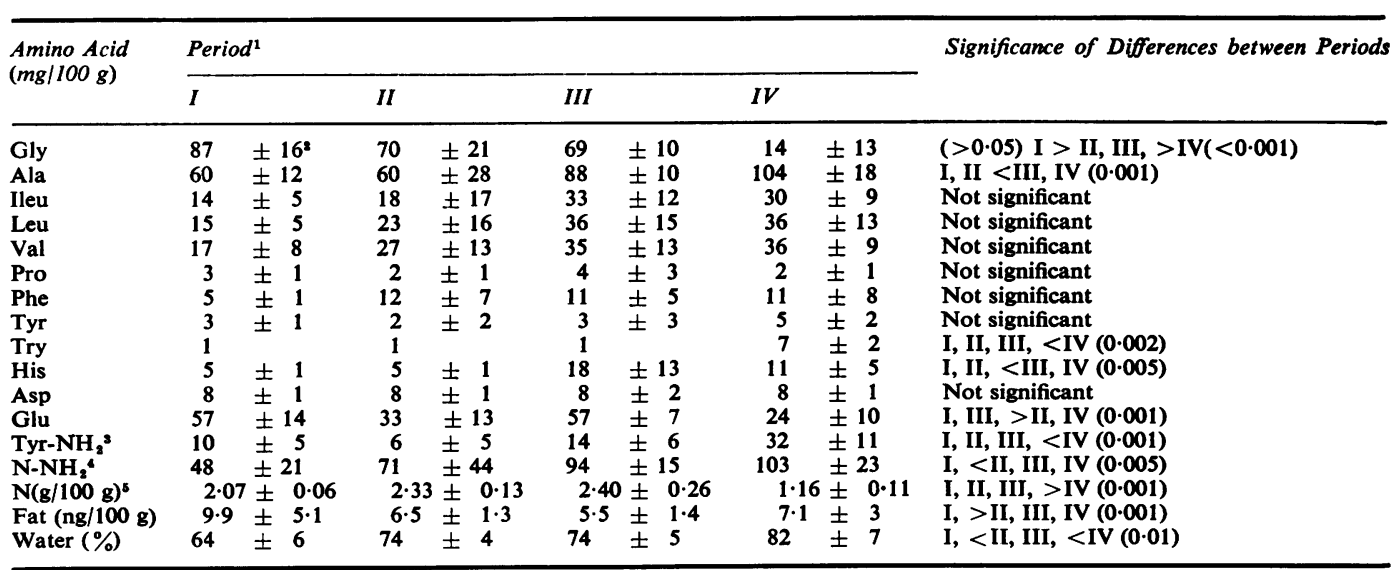

Table IV Changes in faecal composition with dietary fat

${ }^{1}$ Period I, normal diet; II, low long-chain triglyceride (20 g/day); III, low long-chain triglyceride (20 g/day) with medium-chain triglyceride (40 g/day); IV, same triglyceride intake as III with pancreatin added. 'Mean \pm 1 SD. 'Tyr- $\mathrm{NH}_{2}$, tyramine; 'N-NH (TNBS method): ${ }^{5} \mathrm{~N}$, nitrogen. 


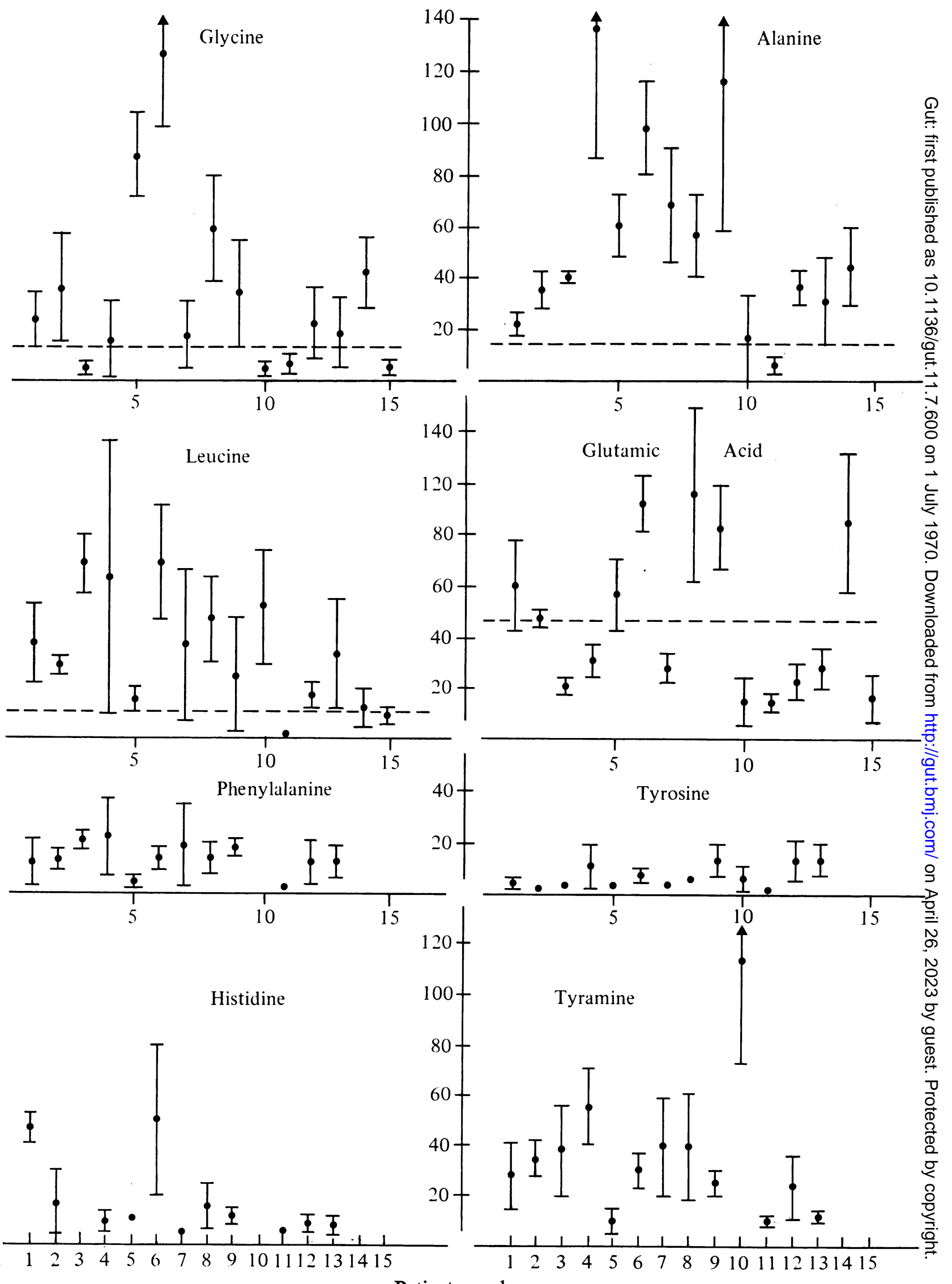

Patient number

Fig. 3 Faecal amino acids and tyramine in cystic fibrosis (mean $\pm 1 S D \mathrm{mg} / 100 \mathrm{ml}$ ). -- - Upper limit of normal (mean $\pm 2 S D$ ). For phenylalanine, tyrosine, and histidine the upper limit of normal is about $2 \mathrm{mg} / 100 \mathrm{~g}$, but tyramine is negligible. 


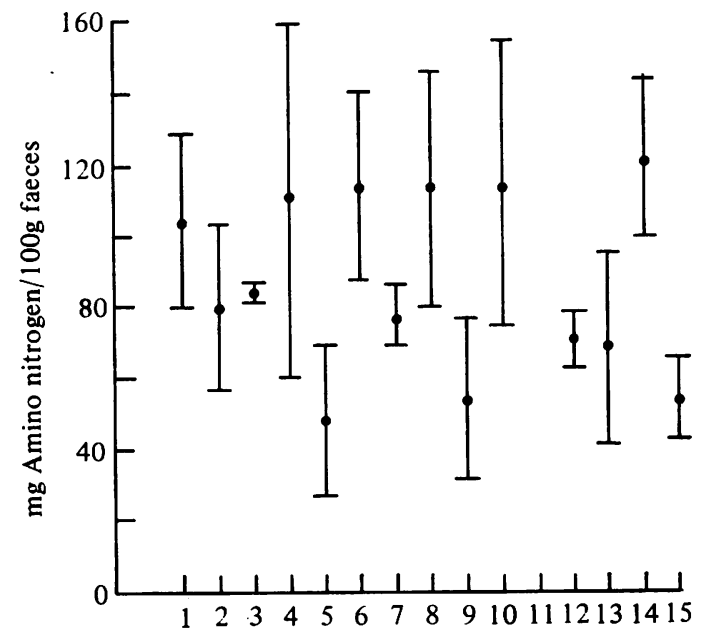

Patient number

Fig. 4 Faecal amino nitrogen (mean $\pm 1 S D)$ in patients with cystic fibrosis.

frequency of defaecation diminished when low long-chain triglyceride $(20 \mathrm{~g} /$ day $)$ with mediumchain triglyceride ( $40 \mathrm{~g} /$ day) was introduced with added pancreatin. The daily fat output fell from $44.2 \mathrm{~g}$ to $11.0 \mathrm{~g} / 24$ hour when long-chain triglyceride was restricted and was further diminished to $6.0 \mathrm{~g} / 24$ hour when pancreatin supplements were added $(P<0.02)$. Gas-liquid chromatography of a saponified petroleum ether extract of acidified faeces when low long-chain tricylceride and medium-chain triglyceride were given demonstrated the absence of $\mathbf{C}_{\mathbf{1 0}}$ and lower fatty acids (Leyland, Fosbrooke, Lloyd, Segall, Tamin, Tomkins, and Wolff, 1969).

In addition to the changes in amino acid composition noted in Table IV, $\delta$-amino-valeric

\begin{tabular}{|c|c|c|c|c|c|c|c|}
\hline \multicolumn{2}{|c|}{ Protein $(\mathrm{g} / 100 \mathrm{~g})$} & \multirow[t]{2}{*}{ Amino Acid } & \multicolumn{5}{|c|}{ Faeces $(m g / 100 \mathrm{~g})($ mean $\pm 1 S D)$} \\
\hline \multirow{2}{*}{$\begin{array}{l}\text { Casein } \\
2\end{array}$} & \multirow{2}{*}{$\begin{array}{l}\text { Gelatin } \\
27\end{array}$} & & \multicolumn{2}{|c|}{$\begin{array}{l}\text { Normal } \\
\text { Diet }(n=4)\end{array}$} & \multicolumn{2}{|c|}{$\begin{array}{l}\text { Gelatin } \\
\text { Diet }(n=5)\end{array}$} & \multirow{2}{*}{$\begin{array}{l}P \\
<0.001\end{array}$} \\
\hline & & Gly & 28 & \pm 18 & 145 & $\pm \mathbf{3 7}$ & \\
\hline 3 & 10 & Ala & 38 & \pm 5 & 20 & \pm 10 & $<0.025$ \\
\hline 6 & 2 & Val & 17 & \pm 5 & 2 & \pm 0.5 & $<0.001$ \\
\hline 6 & 2 & Ileu & 12 & \pm 6 & 0.2 & \pm 0.6 & $<0.005$ \\
\hline 9 & 4 & Leu & 18 & \pm 4 & 1 & \pm 0.7 & $<0.001$ \\
\hline 10 & 14 & Pro & 4 & - & 1 & - & Not significant \\
\hline 5 & 2 & Phe & 10 & \pm 7 & 1 & \pm 1 & 0.05 \\
\hline 6 & 1 & Tyr & 11 & \pm 8 & 1 & \pm 1 & 0.05 \\
\hline 3 & i & His & 9 & \pm 3 & 6 & \pm 2 & Not significant \\
\hline 6 & 7 & Asp & 3 & \pm 1 & 1 & - & Not significan \\
\hline 20 & 11 & Glu & 23 & \pm 6 & 4 & \pm 1 & $<0.001$ \\
\hline 0 & 13 & Hypro & 0 & & 0 & & - \\
\hline 1 & $\mathbf{0}$ & Try & $\mathbf{0}$ & & 0 & & - \\
\hline \multirow[t]{4}{*}{3} & 1 & Met & $\mathbf{0}$ & & 0 & & - \\
\hline & & Tyr-NH & 23 & \pm 5 & 3 & \pm 3 & $<0.001$ \\
\hline & & $\mathrm{N}-\mathrm{NH}_{2}$ & 71 & \pm 8 & 135 & \pm 8 & $<0.001$ \\
\hline & & $\begin{array}{l}\text { N }(g / 100 g) \\
\text { Fat }(g / 100 g) \\
\text { Water }(\%)\end{array}$ & $\begin{array}{l}1 \cdot 32 \\
12 \cdot 6 \\
76\end{array}$ & $\begin{array}{l}2 \pm 0 \cdot 26 \\
\pm 3 \cdot 0 \\
\pm 1\end{array}$ & $\begin{array}{r}1 \cdot \\
12 \\
74\end{array}$ & $\begin{array}{ll} \pm & 0 \cdot 18 \\
\pm & 2 \cdot 2 \\
\pm & 4\end{array}$ & $\begin{array}{l}\text { Not significan } \\
\text { Not significan } \\
\text { Not significan }\end{array}$ \\
\hline
\end{tabular}

Table V Composition of casein and gelatin and the effect of gelatin diet on faecal amino acids

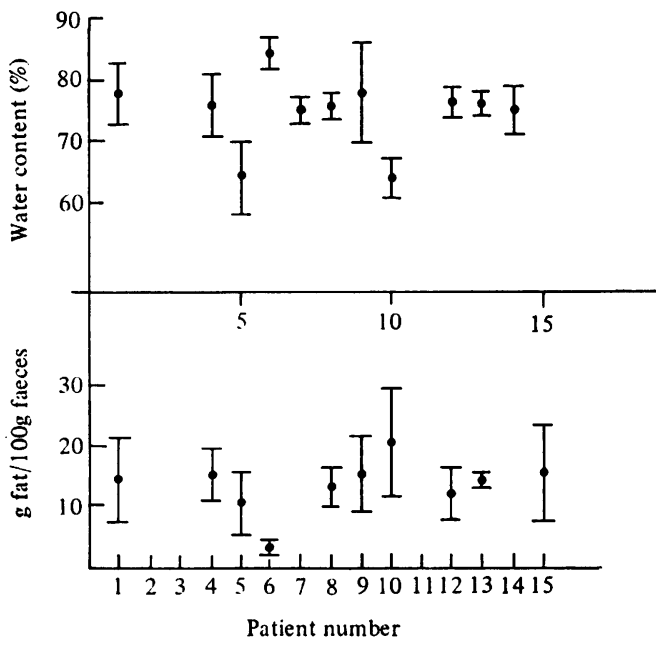

Fig. 5 Water and fat content (mean $\pm 1 S D)$ in patients with cystic fibrosis.

acid was prominent on the electrochromatograms throughout the four periods, whilst lysine, which was virtually absent when the patient was on a normal diet or was given low long-chain triglyceride, or when she was given low long-chain triglyceride with medium-chain triglyceride, was very heavy when pancreatin was also given. This increase in lysine would account for the increase in amino nitrogen. The excretion of p-hydroxyphenylacetic acid varied from normal to grossly abnormal Similar results were obtained in two other patients studied in less detail.

\section{GELATIN DIET}

In three patients with cystic fibrosis, one normal adult, and one infant with normal gastrointestinal function, first-class protein was replaced as far as practicable with gelatin for two days. The faecal amino-acid patterns of the two normal subjects did not change. In one patient (no. 12) who received $43 \mathrm{~g}$ gelatin plus $19 \mathrm{~g}$ first-class protein during the test period as against $60 \mathrm{~g}$ first-class protein in the control period there was a very significant and prompt change in the faecal amino-acid pattern, which quickly returned to the pattern observed in the control period when a normal diet was resumed. Table $\mathrm{V}$ summarizes the results in this patient. Unexpectedly, no hydroxyproline was detected in the test period, $\gamma$-amino-n-butyric acid and $\beta$-alanine decreased, whilst $\delta$-amino-n-valeric acid increased. In the other two patients with cystic fibrosis. the results were not as clear cut as in the first, although the changes in the amino-acid patterns of the first marked stools were of the same order as in the first patient, but subsequent faecal patterns showed greater variation. The following significant changes were noted. In the second patient 
(no. 14) the glycine content increased from $40 \pm 13$ to $100 \pm 5 \mathrm{mg} / 100 \mathrm{~g}(\mathrm{P}, 0.001)$ while glutamic acid fell from $83 \pm 28$ to $15 \pm 5$ (P, $0.005)$, alanine from $47 \pm 22$ to $15 \pm 5(P, 0.05)$, and tryptophan was no longer detectable. In the third patient (no. 13) there was an immediate increase in glycine from $18 \pm 12 \mathrm{mg} / 100 \mathrm{~g} \mathrm{(5-30)}$ to $200 \pm 70(150-300)(P, 0.02)$. As with the first patient, no hydroxyproline was detected in these two test periods. The effect of pancreatin supplements was also investigated in these two patients: no consistent changes in the pattern were observed, except that hydroxyproline was still not detected.

\section{PROTEIN HYDROLYSATE}

The effect of substitution of an enzymic hydrolysate of lactalbumin (Nesmida ${ }^{1}$ ) for whole (milk) protein was studied in five infants with cystic fibrosis, chosen because of failure to thrive. There was an immediate improvement in the faecal amino-acid pattern. Figure 6 shows a serial one-way chromatogram in one patient and the corresponding amino-nitrogen values. The excretion of p-hydroxyphenylacetic acid also diminished considerably.

${ }^{1}$ Nesmida, Nestlé SA, Vevey, Switzerland.
THE USE OF ANTIBACTERIAL AGENTS

Faecal specimens from two patients with cystic fibrosis (aged eight and 13), receiving phthalylsulphathiazole $(800 \mathrm{mg}$ tds) and streptomycire (400 mg tds) for five days, gave heavy bacterial: cultures throughout the period. Those faeca $\overline{\bar{l}}$ amino acids, which were abnormal in the controt period, remained abnormal in the test period을 The excretion of p-hydroxyphenylacetic acidp fluctuated but was still abnormal throughout.

\section{Discussion}

Although visual comparison of amino acid separated by paper chromatography is less accurate than ion-exchange resin chromatography $\overrightarrow{;}$ paper chromatography has the advantages of specificity and speed, and in this study enabled 8 a large number of specimens to be examined.을 Some of the variations observed may be attributedto this.

A careful examination (for details see Ersser, 1969) of the solvent extraction method pre- $\overrightarrow{0}$ viously employed (Seakins and Ersser, 1967) showed that the extraction of faecal amino acids was incomplete, and furthermore the same sample

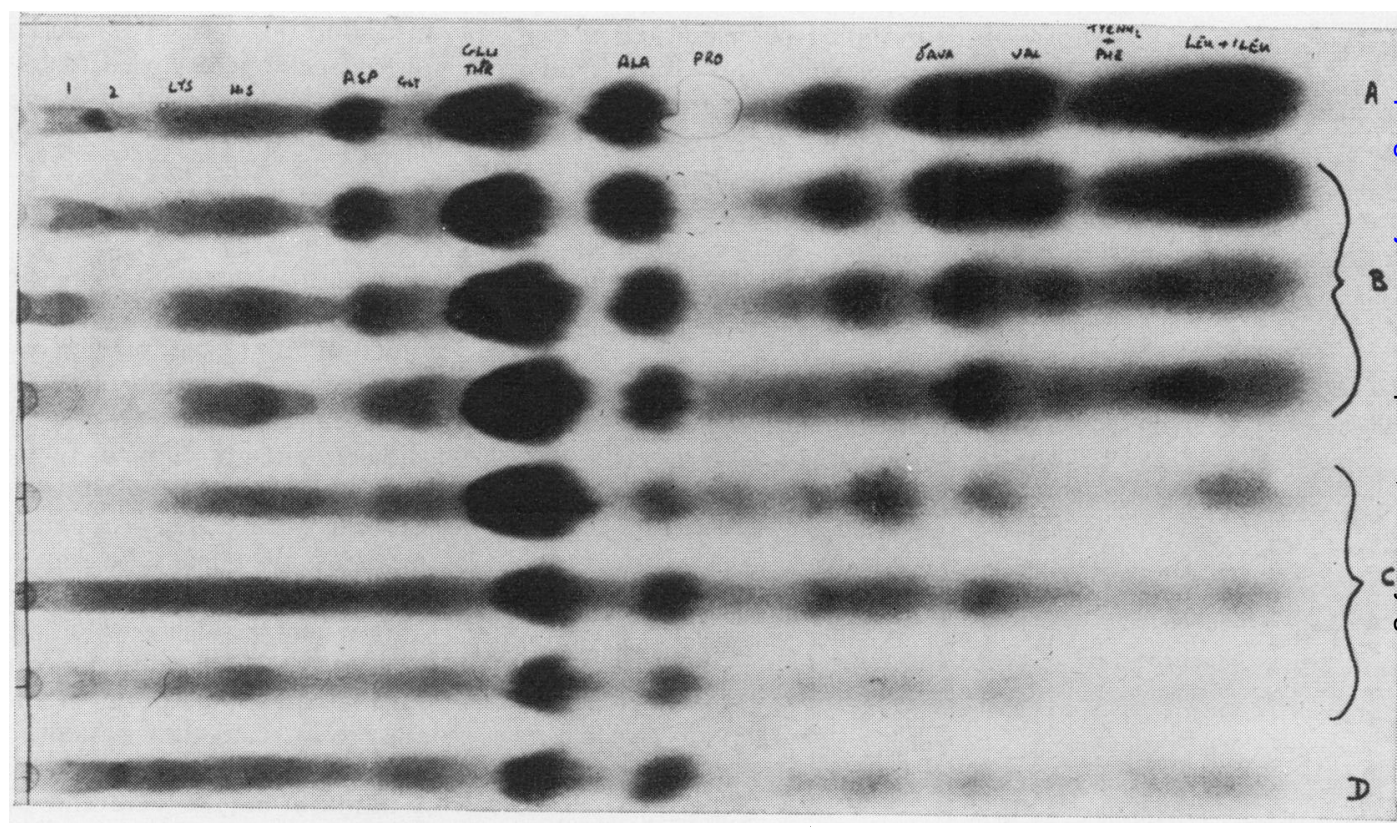

Fig. 6 One-way descending chromatogram of faecal extracts from an infant with cystic fibrosis receiving high protein $(A)$, high protein + pancreatin $(B)$, enzymic hydrolysate $(C)$, enzymic hydrolysate + pancreatin $(D)$. The corresponding amino nitrogen values are: $A, 116 ; B,-, 80,68 ; C, 67,46,33$; $D, 34 \mathrm{mg} / 100 \mathrm{~g}$. 
could not be used for other analyses. Aqueous extraction methods (Bickel, 1964; Hooft, Carton, Snoeck, Timmermans, Antener, van den Hende, and Oyaert, 1968) gave variable increases in amino acids, traced to continued enzymic and bacterial proteolytic activity during homogenization. Homogenization with phosphate buffer followed by extraction into butanol (Yarbro and Anderson, 1966) gave a very poor recovery of amino acids. By using dilute hydrochloric acid, as detailed in the methods section, proteolytic activity was stopped, and an excellent extraction of faecal amino acids was achieved, with the exception of taurine and cysteic acid which are not retained on Zeo-Karb $225\left(\mathrm{H}^{+}\right)$. This method of extraction does not distinguish between intracellular and extracellular amino acids. These observations in part explain the higher values reported by Hooft et al (1968) and the lower $\alpha$-amino-nitrogen values given by Asatoor, Chamberlain, Emmerson, Johnson, Levi, and Milne (1967).

The trinitrobenzenesulphonic-acid method for amino nitrogen (Mokrasch, 1967) was preferred to the specific $\alpha$-amino-nitrogen method of van Slyke, since it was readily automated, is less sensitive to ammonia, and gives a better measure of amino acids (both $\alpha$ and non- $\alpha$ ) and amines than the latter, although oligopeptides retained on the resin and present as a streak with low mobility and $R_{f}$ on the electrochromatograms will also contribute to the colour yield.

The gravimetric method of Fowweather and Anderson (1946) for faecal fats was chosen rather than van der Kamer's since some children were receiving medium-chain triglyceride ( $c f$ Leyland et al, 1969).

The results in normal subjects when the dietary protein was radically altered, earlier work on protein amino-acid loads (Milne, Crawford, Girao, and Loughridge, 1960; Milne, Asatoor, Edwards, and Loughridge, 1961; Seakins and Ersser, 1967), and the study of the fate of cycloleucine (Christensen and Clifford, 1962) show that faecal amino acids in normal subjects are predominantly of bacterial origin or arise through the bacterial action on unabsorbed endogenous protein (Nasset, 1964) rather than by secretion into the large bowel. Likewise, Sheffner, Kirsner, and Palmer (1948) found that the composition of normal faecal protein was little changed when dietary protein was varied.

In contrast to the consistent patterns given by normal subjects, the majority of children with cystic fibrosis gave heavy patterns which varied somewhat from sample to sample in an individual and from patient to patient. It is therefore unlikely that a defect in amino-acid transport analogous to that found in Hartnup disease (Milne et al, 1960) or cystinuria (Milne et al, 1961) operates in cystic fibrosis or excess secretion of amino acids into the large bowel occurs.

In spite of the increased faecal bulk and reduced transit time observed in cystic fibrosis, the water content of faeces was in the same range observed in normal subjects, indicating efficient water absorption from the large bowel.

The total faecal nitrogen comprises proteins, substances such as ammonia and volatile amines which are lost in the column preparation, and amino compounds which are measured by the TNBS method. In view of the high faecal aminonitrogen content found in cystic fibrosis, the finding of the same nitrogen content as in normal subjects was unexpected. This implies that the protein and/or volatile amine content is lower in cases of cystic fibrosis, which is consistent with the observation that these faecal specimens have the same water content but higher fat content than normal specimens. Furthermore, the longer transit time in normal subjects would allow more extensive degradation of any amino acid present to substances such as ammonia. No relationship between total nitrogen, amino-nitrogen, fat, bulk, or water content and the amino-acid pattern of individual specimens was noted in patients receiving a free-choice diet.

Pancreatin was not the major source of faecal amino acids, for heavy patterns were observed in eight newly diagnosed patients before any therapy had been instituted, although there was some evidence to suggest that pancreatin given with ordinary protein further increased the abnormal pattern.

Controlled dietary studies indicated that steatorrhoea was not the cause of the aminoacidorrhoea, although reduction in faecal fat by replacing long-chain triglyceride with mediumchain triglyceride and subsequently adding pancreatin did produce significant changes in some amino acids, which may reflect altered bacterial metabolism.

Direct evidence for the dietary origin of faecal 8 amino acids in cystic fibrosis was obtained from $₹$ investigations in which first-class protein was 웅 replaced by second class. Previous workers $D$ (Anfanger and Heavenrich, 1949; Christensen and Schwachman, 1949; Gould and Shwachman, 1956) showed that gelatin, in common with other proteins, is poorly absorbed in untreated cystic $\tilde{\sim}$ fibrosis. With the exception of alanine, proline, $\underset{\omega}{\omega}$ and hydroxyproline, the prompt changes in faecal amino acids were in the direction anti- 0 cipated from the difference in composition of first-class protein (eg, casein) and gelatin. It is $\stackrel{?}{?}$ known that proline, hydroxyproline, and alanine occur in gelatin (collagen) in sequences such as Gly-Pro-Ala, Gly-Pro-Hyp, Gly-Pro-Gly, which are more resistant to degradation by the usual $\stackrel{\mathbb{Q}}{\stackrel{2}{2}}$ proteolytic enzymes (Grassmann, Hannig, and $\overline{2}$ Schleyer, 1960; Grassman, Nordwig, and Hör- 8 mann. 1961) and this is the most likely explana- $\frac{8}{0}$ tion for the low values found for alanine and proline and the absence of hydroxyproline, rather $\stackrel{\bar{\sigma}}{\rightleftharpoons}$ than degradation of these amino acids.

The improvement in amino-acid pattern follow- 
ing the introduction of an enzymic protein hydrolysate indicated that absorption of (free) amino acids in cystic fibrosis is not seriously impaired, and this is in agreement with earlier observations on the blood amino-acid response following loading tests of casein hydrolysates or glycine (West et al, 1946; Anfanger and Heavenrich, 1949; Rossi and Menano, 1953).

Although the tryptic and chymotryptic activity of faeces from patients with cystic fibrosis not receiving pancreatin is normally negligible (Haverback, Dyce, Gutentag, and Montgomery, 1963) the evidence presented points to bacterial action on unabsorbed (partially digested) dietary protein as an important source of faecal amino acids in these patients. Many bacteria are capable of forming peptidases and proteinases which are more active against denatured proteins than against native proteins (Sokatch, 1969). However, attempts to sterilize the gut were not successful, so that direct evidence for bacterial proteolysis could not be obtained; neomycin cannot be used since it itself produces a malabsorption syndrome (Asatoor et al, 1967).

Non-protein amino acids found in abnormal amounts in faecal specimens from children with cystic fibrosis are most likely derived by bacterial action from protein amino-acid precursors (Meister, 1965); $\beta$-alanine from aspartic acid (also found in babies by Bickel, 1964); $\gamma$-aminon-butyric acid from glutamic acid (in babies, Bickel, 1964; in adults, Asatoor et al, 1967) and first tentatively identified by (Ross 1951), and $\delta$-amino-n-valeric acid (not previously reported) from lysine and proline (Rodwell, 1969). The identity of this last amino acid was confirmed by the procedures outlined in the section on methods. The diamines cadaverine (from lysine) and putrescine (from ornithine) were found in a number of specimens from patients with cystic fibrosis; cadaverine in trace amounts was found in a few normal adults and children in agreement with Abraham, Radonich, and Jones (1968), but putrescine was absent in all normal specimens.

Tyramine was a very common constituent in faecal specimens from children with cystic fibrosis, and is the source of urinary p-hydroxyphenylacetic acid in these patients (Gibbons et al, 1967; Gjessing and Lindeman, 1967), but unexpectedly phenylethylamine and tryptamine were never found in any specimen, although many contained abnormal amounts of phenylalanine and tryptophan, and the tyrosine decarboxylase of $S$. faecalis has considerable phenylalanine decarboxylase activity (Meister, 1965).

The authors wish to thank the Cystic Fibrosis Research Foundation Trust, the Nuffield Foundation, the Joint Research Board of the Hospital for Sick Children, and the Institute of Child Health for financial help; Dr A. P. Norman for permis- sion to study his patients, Dr Barbara E. Clayton for valuable discussion, and Mrs W. Bell and Mrs S. Evans for technical assistance. The authors also thank the Nestlé Company for a gift of Nesmida, and Miss A. Fosbrooke for the gas: chromatography.

References

Abraham, A., Radonich, Z., and Jones, C. T. (1968). Lysine absorption in the small intestine. The relevance of faecaf cadaverixe as an index of lysine malabsorption. Clin. chim
Acta, 22, 619-622.

Anfanger, H., and Heavenrich, R. M. (1949). Amino acid toler- $\vec{P}$ ance tests in children. Amer. J. Dis. Childh, 77, 425-436. $\bigcirc$

Asatoor, A. M., Chamberlain, M. J., Emmerson, B. T., Johnson,J. R., Levi, A. J., and Milne, M. D. (1967). Metabolic $\vec{\omega}$ effects of oral neomycin. Clin. Sci., 33, 111-124.

Bickel, H. (1964). Úber Zucker- und Aminosäurengehalt vono Säuglingsstühlen: Physiologische Grundlagen zur Diagnose von Resorptionsstörungen. Mschr. Kinderheilk.,-, 112, 173-176.

Blau, K. (1961). Chromatographic methods for the study of amines from biological material. Biochem. J., 80, 193-200.'

Christensen, H. N., and Clifford, J. A. (1962). Excretion of $1-8$ amino-cyclopentanecarboxylic acid in $\operatorname{man}$ and the rat. Biochim. biophys. Acta (Amst), 62, 160-162.

Christensen, H. N., and Shwachman, H. (1949). Determinationof the plasma glycine after gelatin-feeding as a diagnostice procedure for pancreatic fibrosis. J. clin. Invest., 28, 319321.

Ersser, R. S. (1969). Ninhydrin positive substances in human $\overrightarrow{0}$ faeces. Thesis for Fellowship, Institute of Medical Laboratory Technology.

Fowweather, F. S., and Anderson, W. N. (1946). A method for $\square$ the determination of fat in faeces. Biochem. J., 40, 350-351.○

Gibbons, I. S. E., Seakins, J. W. T., and Ersser, R. S. (1967). Tyrosine metabolism and faecal aminoacids in cystic
fibrosis of the pancreas. Lancet, $1,877-878$.

Gjessing, L. R., and Lindeman, R. (1967). p-Hydroxyphenylacetic ڤొ acid in cystic fibrosis. Lancet, 2, 47-48.

Gould, B. S., and Shwachman, H. (1956). Studies in cystic fibrosis : determination of plasma proline following protein feeding $\overline{\bar{O}}$ as a diagnostic test for pancreatic insufficiency. Amer. J. 3 Dis. Childh., 91, 584-587.

Grassmann, W. Hannig, K., and Schleyer, M. (1960). Zur Aminosäurensequenzen des Kollagens. II. Hoppe-Seylers Z. physiol. Chem., 322, 71-79.

Grassman, W. Nordwig, A., and Hörmann, H. (1961). Aminosäurensequenzen des Kollagens. III. Hoppe-Seylers Z. physiol. Chem., 323, 48-60.

Harris, R., Norman, A. P., and Payne, W. W. (1955). The effect of pancreatin therapy on fat absorption and nitrogen retentionin children with fibrocystic disease of the pancreas. Arch. Dis. Childh., 30, 424-427.

Haverback, B. J., Dyce, B. J., Gutentag, P. J., and Montgomery, 0 D. W. (1963). Measurement of trypsin and chymotrypsin in stool. A diagnostic test for pancreatic exocrine in- $D$ sufficiency. Gastroenterology, 44, 588-597.

Hooft, C., Carton, D., Snoeck, J., Timmermans, J., Antener, I., van den Hende, C., and Oyaert, W. (1968). Further inves- $N$
tigations in the methionine malabsorption syndrome. Helv. paediat. Acta, 23, 334-349.

Kakimoto, Y., and Armstrong, M. D. (1961). The preparation and isolation of D-(-)- $\beta$-aminoisobutyric acid. J. biol. $\mathcal{W}$ Chem., 236, 3283-3286.

Leyland, F. C., Fosbrooke, A. S., Lloyd, J. K., Segall, M. M., Tamin, I., Tomkins, R., and Wolff, O. H. (1969). Use of medium-chain triglyceride diets in children with mal- $\bar{D}$ absorption. Arch. Dis. Childh., 44, 170-179.

Meister, A. (1965). Decarboxylation. In Biochemistry of the Amino Acids, 2nd ed., vol. I, pp. 325-338. Academic Press, New York and London.

Milne, M. D., Asatoor, A. M., Edwards, K. D. G., and Loughridge, $L$. W. (1961). The intestinal absorption defect in $\frac{\overbrace{\mathbb{D}}}{\text { cystinuria. G.tt, } 2,323-337 \text {. }}$

Milne, M. D., Crawford, M. A., Girão, C. B., and Loughridge, L. W. W. (1960). The metabolic disorder in Hartnup disease. Quart. J. Med., 29, 407-421.

Mokrasch, L. C. (1967). Use of 2,4,6-trinitrobenzenesulfonic 음 acid for the coestimation of amines, aminoacids and proteins in mixtures. Analyt. Biochem., 18, 64-71.

Munier, R. L., and Sarrazin, G. (1964). Amélioration d'un système solvant à haut pouvoir séparateur permettant l'analyse chromatographique sur papier à deux dimensions des mélanges d'amino-acides de grande mobilité. $J$. Chromatogr., 13, 143-147. 
Nasset, E. S. (1964). The nutritional significance of endogenous nitrogen secretion in non-ruminants. In The Role of the Gastrointestinal Tract in Protein Metabolism, edited by H. N. Munro, pp. 83-96, Blackwell, Oxford.

Prenton, M. A., and London, D. R. (1967). The continuous in vivo monitoring of plasma amino-nitrogen. In 5th Colloquium on Amino Acid Analysis, pp. 70-77. Technicon International Division, Domont, France.

Rodwell, V. W. (1969). Proline metabolism and lysine metabolism. In Metabolic Pathways, 3rd ed., edited by D. M. Greenberg, Vol. III, pp. 210-211 and 217-218. Academic Press, New York and London.

Ross, C. A. C. (1951). Faecal excretion of amino acids in infants. Lancet, 2, 190-194.

Rossi, E., and Menano, H. P. (1953). Étude sur les aminoacidémies provoquées dans la fibrose pancréatique avec bronchiectasies. Helv. paediat. Acta, 8, 530-543.

Seakins, J. W. T., and Ersser, R. S. (1967). Effects of amino acid loads on a healthy infant with the biochemical features of Hartnup disease. Arch. Dis. Childh., 42, 682-688.
Sheffner, A. L., Kirsner, J. B., and Palmer, W. L. (1948). Studies on amino acid excretion in man: 2. Amino acids in feces. J. biol. Chem., 176, 89-93.

Smith, I. (1969). Aminoacids, amines and related compounds. In Chromatographic and Electrophoretic Techniques. 3rd ed., edited by I. Smith, vol. 1. pp. 104-169. Heinemann, London.

Smith, I., Seakins, J. W. T., and Dayman, J. (1969). Phenolic acids. In Chromatographic and Electrophoretic Techniques. 3rd ed., edited by I. Smith, Vol. 1., pp. 364-389. Heinemann, London.

Sokatch, J. R. (1969). In Bacterial Physiology and Metabolism, pp. 165-166. Academic Press, London and New York.

West, C. D., Wilson, J. L., and Eyles, R. (1946). Blood amino nit rogen levels: changes in blood amino nitrogen levels following ingestion of proteins and of a protein hydrolysate in infants with normal and with deficient pancreatic function. Amer. J. Dis. Childh., 72, 251-273.

Yarbro, M. T., and Anderson, J. A. (1966). L-tryptophan metabolism in phenylketonuria. J. Pediat., 68, 895-904.

\section{The June 1970 Issue}

\section{THE JUNE 1970 ISSUE CONTAINS THE FOLLOWING PAPERS}

A psychiatric study of patients with diseases of the small intestine DAVID GOLDBERG

Permeability of the small intestine to substances of different molecular weight C. A. LOEHRY, A. T. R. AXON, P. J. HILTON, R. C. HIDER, AND B. CREAMER

Scanning and transmission electron microscopic studies of human intestinal mucosa PETER G. TONER, KATHARINE E. CARR, ANNE FERGUSON, AND COLIN MACKAY

The effect of diet on ileostomy function T. J. THOMSON, J. RUNCIE, AND A. KHAN

Morphological changes of the small-intestinal mucosa of guinea pig and hamster following incubation in vitro and perfusion in vivo with unconjugated bile salts THOMAS S. LOW-BEER, ROBERTO E. SCHNEIDER, AND WILLIAM O. DOBBINS

Small intestinal mucosal abnormalities in relatives of patients with dermatitis herpetiformis JANET MARKS, DAVID BIRKETT, SAM SHUSTER, AND D. F. ROBERTS

The influence of age on the xylose absorption test MARTIN J. KENDALL

Supersensitivity and gastric emptying after vagotomy J. TINKER, N. KOCAK, T. JONES, H. 1 . GLASS, AND ALAN G. COX
Inflammatory bowel disease in ankylosing spondylitis M. I. V. JAYSON, P. R. SALMON, AND W. J. HARRISON

Ligation of the hepatic artery in the treatment of heart failure due to hepatic haemangiomatosis M. O. RAKE, M. M. LIBERMAN, J. L. DAWSON, RACHEL EVANS, E. B. RAFTERY, L. LAWS, AND ROGER WILLIAMS

A clinical and histochemical study of cholestasis V. J. DESMET, A.-M. BULLENS, AND J. DE GROOTE

Plasma insulin in pancreatic disease M. F. ANDERSON, S. H. H. DAVISON, A. P. DICK, C. N. HALES, AND J. OWENS

\section{Technique}

A modified cannula for sampling pancreatic juice in the $\operatorname{dog}$ A. N. FAWCETT

\section{Progress report}

Glucocorticoids and the gastrointestinal tract: current status PAUL CUSHMAN, JR.

\section{Progress report}

Vagotomy for gastric ulcer H. L. DUTHIE

Notes and activities

Copies are still available and may be obtained from the PUBLISHING MANAGER, BRITISH MEDICAL ASSOCIATION, TAVISTOCK SQUARE, WC 1H 9JR price 17s. 6D. 